\title{
Política missionária e secular em escritos jesuíticos sobre a Baixa Califórnia no século XVIII'
}

\author{
Beatriz Helena Domingues \\ Universidade Federal de Juiz de Fora
}

RESUMO

O objetivo deste artigo é analisar a conjugação de preocupações espirituais e temporais nos escritos jesuíticos mexicanos referentes às missões da Baixa Califórnia em meados do século XVIII, período em que a Companhia de Jesus vinha se enfrentando com as reformas bourbônicas. Toma como exemplos os escritos de dois jesuítas: um missionário (Miguel Venegas) e um educador (F. X. Clavijero). Venegas foi missionário na Baixa Califórnia e autor de Notícia de la California y de su conquista temporal y espiritual hasta el tiempo presente (1739). Clavijero foi principalmente um educador, mas envolvido com o desempenho das missões, conforme pode ser visto na sua Historia de la Antigua o Baja California (1790). Ambos são aqui considerados como representantes da geração de jesuítas mexicanos que, poucas décadas antes da expulsão da Cia de Jesus da Nova Espanha, que combinaram trabalho espiritual com o temporal, dos quais resultou uma bem sucedida experiência missionária e uma rica produção intelectual.

Palavras-chave: jesuítas; jesuítas na Baixa Califórnia; ecletismo.

\section{ABSTRACT}

The aim of this article is to analyse the coexistence of spiritual and temporal preoccupations in the Mexican Jesuit writings on the Low California missions by the middle of the eighteenth century, when the Society of Jesus were facing the Bourbon Reforms. It takes as examples the writings of two Jesuits: a missionary (Miguel Venegas) and an educator (F.X. Clavijero). Venegas was a missionary in Low California and author of Notícia de la California y de su conquista temporal $y$ espiritual hasta el tiempo presente (1739). Clavijero was mainly an educator, but involved with the performance of the missions as can be seen in his Historia de la Antigua or Baja California (1790). Both are here considered as representatives of a generation of Mexican Jesuits who, few decades before the expelling of the Society of Jesus from New Spain, combined their spiritual with their temporal works, whose result was a successful missionary enterprise and a rich intellectual production.

Keywords: jesuits; jesuits from Low California; Eclecticism. 
A idéia deste artigo é analisar a conjugação de preocupações espirituais e temporais nos escritos jesuíticos mexicanos referentes às missões da Baixa Califórnia em meados do século XVIII, período em que a Companhia de Jesus vinha se enfrentando com as reformas bourbônicas. Toma como exemplo os escritos de dois jesuítas: um missionário e um educador. Miguel Venegas, missionário na Baixa Califórnia por muitos anos e autor de Notícia de la California y de su conquista temporal y espiritual hasta el tiempo presente [1739] é aqui considerado como representante da geração de jesuítas mexicanos que, poucas décadas antes da expulsão da Cia de Jesus da Nova Espanha, acrescentavam ao seu trabalho missionário - que era também temporal, envolvendo desde construção e comércio até defesa militar - uma rica produção intelectual. Seu trabalho enfatiza a descrição da difícil experiência missionária dos jesuítas na Califórnia, e como, a partir dela, foram aperfeiçoando sua catequese. Ao mesmo tempo, faz referências às "descobertas" históricas e geográficas que deveriam ser levadas em conta pela Coroa espanhola em sua política em relação à região em termos de comércio, navegação e defesa estratégica do império espanhol, confrontado então com a expansão de ingleses e russos em direção às terras da Califórnia, especialmente aquelas mais ao norte, onde a presença espanhola era ainda incipiente. Clavijero - educador e ativo participante na chamada "Disputa do Novo Mundo" - escreveu sua Historia de la Califórnia [1780] durante seu exílio na Itália com o propósito de defender a América de seus "detratores iluministas" e de escrever algo mais apropriado para o seu tempo do que seus colegas jesuítas vinham até então fazendo. Curioso no texto de Clavijero é a ênfase no trabalho missionário na Baixa Califórnia como um dos melhores empreendimentos da Coroa no Reino da Nova Espanha, onde ele próprio havia atuado como educador, ainda que não como missionário. No relato histórico que faz do empreendimento missionário jesuítico na Califórnia, Clavijero historia, ao mesmo tempo, a política de incentivo da Coroa espanhola, enfatizando o seu decréscimo com o início das reformas bourbônicas. E suas conclusões e conselhos à Coroa aproximam-se dos de Venegas: ambos vinculam o progresso material do empreendimento colonial ao sucesso do projeto missionário.

Ao discutirmos a obra de Clavijero, a idéia é contextualizar os escritos jesuíticos sobre a Califórnia no interior da "Polêmica do Novo Mundo": suas respostas às teses formuladas pelos filósofos iluministas sobre a natureza e os homens do continente americano, seguida de uma análise sobre a solução político-religiosa oferecida por eles à Coroa espanhola, que então iniciava a implantação das reformas bourbônicas no Reino da Nova Espanha, do qual fazia parte a península da Califórnia. A fim de melhor caracterizar o teor da "defesa" da Califórnia por Clavijero, contrasto esta obra com a sua anterior História antigua de México, na qual dedica um volume, intitulado Disserta- 
ciones, a defender a América, ou mais especificamente o México das teses dos filósofos e naturalistas iluministas europeus. A seguir estabeleço paralelos entre as opiniões de Clavijero e Venegas sobre a Califórnia, e especialmente sobre a posição estratégica ocupada pela referida península no interior do império espanhol por ocasião da implementação das Reformas Bourbônicas. A história da Companhia de Jesus na Califórnia escrita por Clavijero - pois é disso que trata, em grande medida, sua Historia de la California - apresenta similaridades e singularidades quando comparada com a de outros jesuítas anteriores e contemporâneos a ele. Destaque especial será dado à obra do jesuíta Miguel de Venegas, reconhecida fonte utilizada e criticada por Clavijero. No embate/debate entre Clavijero e Venegas fica evidente a heterogeneidade no interior do pensamento jesuítico: Clavijero representando mais os "colégios" e Venegas mais as missões, mas sem supor que exista uma clivagem completa entre as duas possíveis opções feitas pelos inacianos. Se parece inegável o maior envolvimento emocional de Venegas com as terras e as gentes da Califórnia, não é menor o de Clavijero com a natureza e população do México. Comum a ambos é o uso de fontes jesuíticas para suas respectivas Histórias da Califórnia e a interação nelas encontrada entre história, natureza e religião, conforme fica claro em suas abordagens do clima, topografia e costumes dos habitantes. O caráter jesuítico das fontes é fundamental para que se perceba um processo de diálogo entre a prática missionária e as formulações teóricas jesuíticas.

O objetivo desta obra de Venegas, como de muitas outras do período, não parece ser meramente apontar os méritos da ação missionária da Cia. de Jesus, senão reforçar como o sucesso material (temporal) da colonização espanhola na Nova Espanha dependeu do sucesso espiritual do empreendimento jesuíta. A ênfase nessa tese é ainda maior quando se refere aos territórios áridos e remotos de Sonora, Baixa Califórnia e Novo México, ocupados por missionários franciscanos antes e depois do "período jesuítico" (1697-1767). Isso fica bem claro na obra do jesuíta Miguel de Venegas, especialmente na quarta parte, onde o autor clarifica a utilidade, para a Coroa espanhola, da conquista espiritual da Califórnia pelos jesuítas. Tanto o texto de Clavijero quanto o de Venegas parecem orientados a provar a importância estratégica da Califórnia para a Coroa. Consideradas as diferenças, em ambos é possível perceber a ênfase na importância do trabalho missionário na Califórnia sob o aspecto de um movimento estratégico para a Coroa preservar suas fronteiras da Nova Espanha (especialmente as do norte) e como os jesuítas haviam sido e continuavam a ser os mais capacitados para levar adiante o empreendimento, devido especialmente à sua experiência missionária em locais reconhecidamente tão remotos e em contato com tribos tão bárbaras e arredias. Desde fins do século XVII, argumentam eles, eram os inacianos que conheciam a língua e costumes 
de várias tribos, já haviam evangelizado várias delas, e mesmo inovado em termos de técnicas pedagógicas para atingir outras mais arredias. Sem sua atuação missionária, as fronteiras ao norte da Nova Espanha estariam inteiramente desprotegidas da expansão inglesa e russa na região.

Percebe-se claramente desses escritos, a ativa participação desses dois jesuítas tão diferentes em outros aspectos, em uma batalha ideológica pela defesa da Cia de Jesus, centrada particularmente no trabalho missionário, contra o crescente antijesuitismo do "Século das Luzes", que perpassava as reformas bourbônicas levadas a cabo na segunda metade do século XVIII, e que implicaram a definitiva expulsão dos inacianos da Nova Espanha e Baixa Califórnia (ainda que esta parte do Reino da Nova Espanha fosse reconhecida, pelo próprio déspota esclarecido e seus assessores, como tendo finalidades estratégicas para os interesses da Coroa). A inter-relação entre o sucesso espiritual e material da Cia. de Jesus, na Europa e na América, é um fenômeno que tem sido reconhecido por vários historiadores não-jesuítas. François Chevalier, por exemplo, mostra como a Companhia de Jesus integrava à sua rígida disciplina interna uma sólida organização econômica, atitude que não era proibida pelas regras da ordem ${ }^{2}$. Após fundar escolas nas principais cidades da Nova Espanha em fins do século XVI, um grupo significativo de jesuítas gradualmente dedicouse à criação de uma cadeia de missões nos extensos territórios do noroeste. Enquanto outras ordens religiosas davam sinais de abatimento em seu trabalho missionário e educacional, os rígidos princípios e a inquestionável superioridade do sistema educacional dos filhos de Loyola atraíam amigos poderosos entre nobres, ricos mineiros (espanhóis ou crioulos) e espanhóis, que freqüentavam as suas escolas. O mais famoso apoio conseguido pelos jesuítas foi o de um homem de negócios, Alonso de Villaseca, que teria aconselhado os jesuítas a complementarem o sustento de seus colégios com haciendas. Como os colégios eram alta prioridade na Nova Espanha, o vice-rei Martín Enriquez fez vista grossa quando o Colégio Maior de São Pedro e São Paulo adquiriu terras para plantar e criar gado, e continuou a fazê-la nos anos seguintes. Nessa ocasião, muitos dos poderosos mercadores da Cidade do México e Puebla, ou mesmo grandes mineradores, tornaram-se amigos ou benfeitores dos jesuítas. A aristocracia agrária não era tão generosa, provavelmente porque tinha menos dinheiro, ainda que fosse sempre aberta a alianças com os ricos mercadores. Em suma, em um período no qual a Igreja ainda era proibida de comprar, e mesmo de possuir propriedades nas Índias, os jesuítas sistematicamente construíram seus ricos "Estados" em um espaço de tempo impressionantemente curto e sem maiores dificuldades ${ }^{3}$.

Embora o ecletismo filosófico fosse uma opção intelectual inerente ao pensamento cristão desde pelo menos o século III, ele assumiu contornos singulares com a nova escolástica do século XVI, cujos principais representantes 
foram os jesuítas. Inclui-se entre os propósitos deste texto especular sobre a relação entre emergência de práticas religiosas sincréticas na experiência missionária jesuítica nas Américas - especialmente do sincretismo religioso que emergiu na Nova Espanha desde o início da colonização - e o ecletismo filosófico dos inacianos nos séculos XVI, XVII e XVIII. Ou seja, como se estabeleceu o contato/diálogo entre missionários e teóricos jesuítas: teria ele acompanhado um movimento (dilema) interno da Companhia de Jesus, orientada, a princípio, prioritariamente para o trabalho missionário, mas paulatinamente priorizando os colégios? Que alterações no uso do "nosso modo de proceder" estiveram presentes nessa reversão e/ou combinação de prioridades em termos de projeto evangelizador? Se for correto ponderar que foi a partir dos colégios que os jesuítas influíram mais poderosamente na sociedade colonial, a ponto de deixar a sua marca na vida acadêmica mesmo depois da sua expulsão, não se pode menosprezar o fato de ter sido da prática missionária que emergiam mudanças conceituais, incluindo conhecimentos geográficos, históricos e de filosofia natural, e mesmo novas práticas pedagógicas. Mudanças essas que tiveram influência nas formulações ecléticas elaboradas na Nova Espanha e na Europa, e cuja influência na vida acadêmica da Nova Espanha sobreviveu à expulsão dos jesuítas.

\section{A História da Califórnia de Clavijero E A "Polêmica do Novo Mundo"}

A estrutura da História do México (1787) e da História da Califórnia (1790), escritas por Clavijero, se parece: começam com uma descrição geográfica, seguida da apresentação da flora e da fauna; depois um histórico de seus habitantes antes e depois da conquista pelos espanhóis. São diferentes, contudo, tanto no que se refere ao objetivo quanto à metodologia utilizada. Diferentemente da História do México e das Dissertaciones, a História Antigua de la Baja California não foi, segundo seu autor, escrita explicitamente para combater os "filósofos iluministas". No prefácio à sua História de la antigua o Baja California, Clavijero enuncia que, embora não sinta por ela o patriotismo que sente em relação ao México, sente-se agredido pelas "calúnias" que os "filósofos iluministas" - Buffon, De Pauw, Raynal e Robertson escrevem sobre ela. Não só por ser a Califórnia parte do continente americano, mas também por se constituir em um importante reduto jesuítico. Na qualidade de jesuíta, admite o empreendimento da Cia. de Jesus no que considera um território nada aprazível. No tópico do clima ou mesmo dos habitantes, Clavijero não está interessado em defender a Califórnia. As "calúnias" de De Pauw e 
dos outros filósofos iluministas que ele se propõe a responder nesta obra referem-se a outros tópicos.

O que se percebe pela leitura da obra é que, embora apareçam algumas críticas aos "filósofos iluministas" — mais especialmente a Robertson —, com bastante freqüência Clavijero utiliza-se de argumentos tipicamente pauwnianos visando a comprovar a superioridade do México e dos mexicanos sobre a Califórnia e os californianos. Em outras palavras, no contexto geral do pensamento de Clavijero, não faria sentido escrever uma História da Califórnia para desacreditar Buffon e De Pauw uma vez que, já na História do México, quem ele faz questão de defender, em termos de aproximá-los dos europeus, são os mexicanos (e peruanos), e não todos os índios americanos. Quanto aos índios bárbaros, entre os quais sem dúvida se incluem os californianos, ele faz poucas restrições aos adjetivos derrogatórios empregados pelos autores acima mencionados. Poucas não significa nenhuma. Pois, se não existe aqui o mesmo grau de patriotismo da outra obra, ele não está tampouco totalmente ausente. A maior preocupação parece ser, como a do colega jesuíta Venegas, com a continuidade do empreendimento jesuíta e espanhol nas remotas, áridas e bárbaras áreas da Califórnia.

Outra importante diferença refere-se ao conhecimento do autor sobre os dois lugares e sobre as duas histórias. Ao escrever a História de la California, Clavijero reconhece estar pisando em terreno menos firme do que quando escreveu a Historia de México, por depender exclusivamente de testemunhos alheios. Daí prescindir de fazer afirmações sobre aspectos que considera "não muito bem esclarecidos". A discussão sobre até que grau de latitude norte teria se expandido a fronteira espanhola seria um exemplo. O que Clavijero tem por certo são os descobrimentos feitos até 1770. Quanto ao suposto avanço até o grau 55, confessa não ter lido ainda os relatos referentes a ele 4 . Em termos de fontes disponíveis para o estudo da Califórnia, esclarece ele que, seguindo-se ao reconhecimento e estabelecimento de muitas missões jesuíticas na península, foi recentemente publicada a História da Califórnia do jesuíta Miguel Venegas. Utilizou-se também Clavijero de cartas dos missionários, especialmente as dos padres Salvatierra, Piccolo e Ugarte - "que foram inspiradas na célebre e antiga história manuscrita de Sonora, composta pelo infatigável pe. Kino" -, do diário do capitão governador da Califórnia don Estevan Rodriguez Lorenzo, das memórias do erudito pe. Segismundo Taraval e de outros documentos originais encontrados nos arquivos do México.

As Investigaciones filosoficas de De Pauw contêm, adverte-nos ele, "em uma única página dedicada a tratar dessa região, 48 falsidades, que tive a paciência de contar, envolvendo erros simples, mentiras formais e calúnias temerárias". Clavijero limita-se a comentar apenas quatro delas: 1) a afirmação de que o tigre é o principal animal da Califórnia, onde também encontram- 
se manadas de bisontes; 2) a tese sobre as vinhas que teriam sido descobertas por um colono espanhol em 1690, e depois cultivadas pelos jesuítas, cuja produção vinícola seria capaz de abastecer todo o México e ainda ser exportada para as Filipinas; 3 ) a denúncia de que o M. Anson foi o primeiro a descobrir, por causalidade, em fins de 1774, que a Cia. de Jesus era poderosamente perigosa naquele rincão do mundo; 4) a que afirma que muitas das tribos californianas que se mantêm na barbárie conservam o hábito de mutilar os membros, cortando algumas falanges dos dedos com a morte de seus parentes ${ }^{5}$.

$\mathrm{Na}$ medida em que Clavijero organiza sua refutação às quatro teses acima enumeradas, o jesuíta utiliza-se basicamente de relatos de missionários jesuítas que viveram ou ainda vivem na região, mas nem sempre especificando se o que afirmam os missionários foi baseado em suas próprias experiências ou em relatos de outros missionários ou informantes indígenas.

Se o objetivo geral da História da California, ainda que em menor medida que a Historia Antigua de México, continua a ser o combate às teses dos "filósofos iluministas", é curioso notar como o próprio Clavijero recorre a alguns argumentos pauwnianos para provar a superioridade do México em relação à Califórnia. Dentre eles, vale destacar a superioridade da religião dos mexicanos: ela é evidente por si mesma, até porque a religião dos californianos é considerada como sendo "quase inexistente". Expressa tal opinião, e outras sobre a religião dos californianos, baseado "em diligentes pesquisas encontradas nos escritos de doutos missionários". Quase todos esses missionários declararam-se admirados de encontrar, nos dogmas dos bárbaros californianos, muitos sinais, ainda que desfigurados, das verdades cristãs ${ }^{7}$. É válido lembrar que seus predecessores jesuítas do século XVII já vinham desenvolvendo uma atitude mais flexível em relação às religiões indígenas e asiáticas, que Otávio Paz denominou sincretismo universalizante: um raciocínio basicamente neoplatônico que permite encontrar, nas mais diferentes culturas e religiões, manifestações de uma verdade universal (ou o Bem platônico $)^{8}$. Seguindo os passos deles, Clavijero explora as diferentes hipóteses que poderiam explicar as semelhanças e ao mesmo tempo o grande afastamento em relação à verdade cristã em que se encontravam os índios californianos. A que lhe parece mais provável é que tenham sido instruídos por alguns cristãos antes da entrada dos jesuítas na península. Pois se sabe que nos 50 anos anteriores ao empreendimento jesuítico, lá chegaram muitas embarcações do México e de outras partes, embora nenhuma delas tenha permanecido tempo suficiente para aprender línguas tão difíceis. De forma que os próprios californianos, quando indagados sobre a origem da sua idolatria, respondem que a haviam recebido de seus antepassados. 


\section{A história da Cia. de Jesus na PEnínsula}

DA CALIFÓRnia NOS ESCRITOS DE Miguel Venegas

Padre Venegas é considerado por alguns como um dos mais talentosos historiadores do século XVIII na Nova Espanha9 ${ }^{9}$, por outros como um reacionário $^{10}$. Também não há concordância sobre sua real participação no empreendimento missionário na Califórnia. Embora o livro apresente-se como resultado de sua experiência pessoal nas missões californianas, fontes jesuíticas assinalam que a precariedade de sua saúde não lhe permitiu longas estadias nas missões. O mais provável é que Venegas tenha estudado a correspondência e informes dos missionários, chegando a enviar questionários a vários deles, com a ajuda de Juan B. Luyando em 1737. O resultado foram as Empresas apostólicas que Andrés Burriel reelaborou - inclusive adicionando conhecimentos que só vieram à tona anos após o manuscrito original de Venegas - e publicou em Madri em 1757 com o título Notícia de la California y de su conquista temporal y espiritual hasta el tiempo presente, assinando com o seu próprio nome ${ }^{11}$. Como as adições/correções parecem não ter sido poucas, consideramos útil adotar a nomenclatura sugerida por Peter Masten Dunne para o(s) autor(s) da edição de 1758: Venegas-Burriel ${ }^{12}$. Devido a revisões e esforços múltiplos de objetividade, a obra não satifez aos missionários e motivou a Juan Baegert, Miguel del Barco e Clavijero a escreverem seus próprios tratados sobre o tema. Ainda assim, a Notícia de la California foi considerada decisiva para a história californiana. Como historiador, Venegas era cuidadoso na investigação, crítico em selecionar as fontes e sobretudo preocupado em descobrir a verdade ${ }^{13}$.

O objetivo do livro é, segundo seu autor(s), uma descrição o mais completa e clara possível da Califórnia, pois "baseada no método mais acurado". Tal descrição poderia contribuir significativamente para a descoberta de uma passagem ao norte que ligasse a América ao Oriente (onde os jesuítas tinham seus próprios entrepostos), uma preocupação que começou no século XVI, mas que não havia sido de todo abandonada no século XVIII. Antes dos jesuítas, adverte-nos, os estudos mais exatos foram os relatos do general Sebastián Vizcaino, que visitou a região em 1602 por ordem de Felipe II $^{14}$. Dentre os jesuítas, Venegas-Burriel diz-se admirador, em especial, do pe. Kino.

No texto de 1758, Venegas-Burriel assinala como as questões referentes à Califórnia foram tão incompletamente examinadas, gerando as gritantes contradições que emergem dos relatos. Venegas-Burriel parece fazer questão de reconhecer que mesmo seus colegas da Cia. de Jesus, "criados no seio das ciências e artes curiosas e úteis”, sentem a falta de instrumentos de observação já disponíveis em outros países ${ }^{15}$. Não limitando-se a lamentar tais carências, Venegas-Burrriel aponta "alguns documentos mais modernos" sobre latitude 
e longitude que pôde conseguir, esquivando-se de referências aos mais antigos e conhecidos ${ }^{16}$. Os jesuítas em geral, e Venegas-Burriel em especial, escolhem uma posição intermediária, congruente com o ecletismo que vinha caracterizando o trabalho intelectual e missionário dos inacianos desde o século XVI. No que se refere aos relatos anteriores sobre a Califórnia, admite o autor: "há um pouco de falsidade em cada um dos relatos, mas tomados em termos gerais há um pouco de verdade neles"17. A Califórnia, embora seca e estéril no interior, é bem menos incômoda para a vida em suas praias, além de ser possível encontrar vales com água para beber e regar no próprio interior da península ${ }^{18}$. Ambas estavam sempre próximas dos rios e riachos, "para que os índios se acostumassem à vida cristã e política, reduzidos a pueblos”. Mas, como não julga dispor de informações suficientes para falar com certeza e exatidão sobre essa questão, utiliza-se do argumento eclético de deixar a decisão por conta do leitor ${ }^{19}$.

No que se refere à "antiga falsa religião dos californianos". divide-a em dois tipos: a dos índios que viviam no continente e que eram, "quando os espanhóis os encontraram, inteiramente livres de qualquer noção idólatra, tendo poucos ou mesmo nenhum ritual, já possuindo até mesmo algumas opiniões especulativas bastante singulares"; e a dos residentes nas ilhas, inversamente, que "eram pessoas profundamente escravas de suas próprias superstições" ${ }^{20}$. A segunda parte da obra lida com a História da Califórnia desde o tempo em que foi descoberta até a chegada dos jesuítas. Na primeira metade do século XVIII, Felipe V (1701-1746) emitiu várias Cédulas garantindo a presença jesuítica na Califórnia, tida como especialmente necessária após as revoltas ao sul por volta de 1734 . Havia uma coincidência entre os objetivos da Monarquia e os dos missionários, entre o temporal e o espiritual, no sentido de expandir o sistema de missões até Gila e ao Colorado, e então à Alta Califórnia. Daí Felipe V ter confirmado a completa autoridade dos missionários sobre soldados e marinheiros: "sem aquelas ordens [dos missionários], os soldados talvez não consigam conviver com os índios, atacando-os, punindo-os, ou fazendo quaisquer outras coisas" ${ }^{\prime 2}$.

Clavijero confirma ter tido notícia não só da publicação das Noticias de la California, pelo pe. Miguel Venegas, como também das condições em que ocorreu a publicação. Clavijero começa alertando-nos que não há nada de história natural na História Natural e Civil da California ${ }^{22}$, que carece também de muitas notícias essenciais e abunda em erros, mesmo que desculpáveis. As obras dos abades Miguel del Barco e dom Lucas Ventura, "homens muito práticos, exatos e sinceríssimos", tentaram remediar os erros de Venegas. O abade del Barco foi missionário por 30 anos e visitou todas as missões da Califórnia. Embora não fosse naturalista por profissão, nem as importantes ocupações de seu ministério lhe permitissem dedicar-se ao estudo da na- 
tureza, "ele era um aficionado de tais observações e, estando dotado de bom juízo e crítica, pôde observar e depois escrever com bastante exatidão sobre o terreno, o clima, produções e animais da Califórnia”. O abade Ventura foi ainda missionário de Loreto por 11 anos, sendo também procurador daquelas missões. Por essa razão, estava muito bem informado sobre todos os negócios daquela península. Os dois teriam corrigido os erros da edição espanhola de Venegas, adicionando-lhe o ensaio de história natural e as notícias de que carecia, continuando a narração até o ano de $1768^{23}$. Clavijero reconhece o mérito desses autores, dos quais se valeu para a confecção da sua história verdadeira e natural da Califórnia. Coerentemente com a crítica comumente feita àqueles que escrevem sobre regiões nas quais não estiveram, o jesuíta mexicano - que não conhece a Califórnia — pede que seu livro seja revisado por duas pessoas com prática naquele país, embora esclareça que tentou unir os conhecimentos obtidos em livros com informes verbais de pessoas que residiriam na Califórnia por um longo tempo.

É importante notar a ambigüidade de Clavijero quando se trata de informar seus leitores sobre as fontes nas quais se apóia. Ele cita integralmente os livros que combate: as Investigações filosóficas de De Pauw e a História da América de Robertson, mas não aqueles que lhe dão suporte: Salvatierra, Piccolo, Ugarte. O único escrito jesuítico sobre o qual fornece informações bibliográficas é a História da Califórnia do pe. Miguel Venegas. Embora baseie nele sua resposta à quarta calúnia de De Pauw (vista acima), sua atitude em relação à obra de Venegas é mais de crítica do que de enaltecimento. Mesmo nesse caso, Clavijero não especifica a parte ou página do livro de Venegas, como o faz em relação a De Pauw e Robertson. No decorrer da obra, os relatos (jesuíticos) mais citados são os padres Kino e Salvatierra, pioneiros na colonização e evangelização da Califórnia, mas também estudiosos de sua geografia e de seus habitantes. São também importantes os relatos de viajantes, como o capitão Vizcaino, por exemplo, já amplamente citado por Venegas.

\section{A IMPORTÂNCIA DOS JESUÍTAS NA CONQUISTA E COLONIZAÇÃO \\ DA CALIFÓRNIA, BEM COMO PARA SUA PERMANÊNCIA NAS FRONTEIRAS DO IMPÉRIO ESPANHOL, NOS ESCRITOS DE Miguel Venegas E ClaViJero.}

Por que estaria Venegas-Burriel valorizando uma região reconhecidamente árida, infeliz, ingrata e miserável? A Califórnia, esclarece ele, já demandou, para a sua conquista e redução, extraordinários gastos e diligências da Coroa espanhola desde os tempos de Hernán Cortés. Tal redução foi finalmente alcançada pelos padres jesuítas no século XVIII, graças à Providência Divina. Por que seria então sua conquista tão importante? Venegas-Burriel 
argumenta que, apesar da miséria e pobreza, a situação geográfica da Califórnia é preciosa: o que torna sua conquista e conversão à religião cristã prioritária em relação a "outros países” da América ${ }^{24}$. Respondendo mais pormenorizadamente à questão, o autor desenvolve duas ordens de argumentos: os chamados "motivos antigos" e os "motivos modernos". Dentre os antigos, o primeiro seria o fato de a Califórnia desempenhar um papel essencial na conexão com as províncias fronteiriças do "continente da Nova Espanha". A sujeição da Califórnia a Deus e ao rei é essencial para que os vecinos possam dar prosseguimento à pesca de pérolas oferecidas pelo golfo da Califórnia, e para que se impeça o contrabando por mar, de uma província para outra, desde Acapulco até o rio Colorado. Pois é sabido que a Califórnia tem dado abrigo a vários piratas e corsários que por ali passam. E seria de grande temor e risco para o "Império Mexicano" se alguma potência estrangeira conseguisse fortificar-se e estabelecer-se na Califórnia ${ }^{25}$.

A Califórnia não é, todavia, menos importante para o progresso da fé e expansão dos domínios do rei espanhol na América Setentrional. Como o autor já havia mostrado na terceira parte, as missões jesuítas não se restringiram às "ricas províncias de Culiacán, Sinaloa, Ostimuri, Yaqui e Sonora, mas avançaram até a Baixa e a Alta Pimería, penetrando até os grandes rios Gila e Colorado, avistando as fronteiras dos Moqui, no Novo México". Faltava ainda finalizar a redução dos papagos, guaimas, tepocas e seris, habitantes da última costa estéril do continente da Nova Espanha, sobre o golfo do México, que acabam de rebelar-se, matando os seus missionários e unindo-se aos "ferozes apaches”. A redução desses índios será sempre muito difícil em se tentando entrar em suas possessões por terra; mas muito fácil se penetrando em suas costas pela fronteira da Califórnia, como nos mostrou a experiência do pe. Salvatierra. Em suma, a conquista espiritual e temporal da Califórnia abriria imensas possibilidades de expansão territorial para o império espanhol ${ }^{26}$. E, para tal, o autor oferece uma verdadeira estratégia militar:

Quanto poderia progredir e apressar essa conquista espiritual e temporal se, de uma só vez, se missionários subissem o Golfo da Califórnia pelos dois lados, reduzindo as nações intermediárias, até unirem-se uns e outros às margens do Rio Colorado, continuando desde ali, juntos, até atingir as ditas costas, portos, cabos e rios sobre o Mar do Sul? ${ }^{27}$

A Califórnia serviria também de porta de comunicação entre a Cidade do México, o Mar do Sul e regiões longínquas ao norte, tão freqüentemente desprovidas de roupas, utensílios e mantimentos. Sem esses portos e comunicação por mar é impossível manter missões, e muito menos colônias, pueblos, estâncias e haciendas de famílias espanholas em tão remotas províncias. 
Mesmo no caso de se conseguirem certos melhoramentos em regiões como Pimería e Sonora, como teriam eles continuidade sem uma comunicação marítima, e convivendo com índios tão bárbaros? O veredicto de Venegas-Burriel é simples: a situação da Califórnia torna-a um lugar essencial para a conservação e expansão da fé, da cristandade e do domínio espanhol na América ${ }^{28}$. A Coroa devia ter em mente que a conquista de tão importante região se deu de forma rápida, desde meados do século XVII, quase sem ajuda do governo, sob a liderança de missionários jesuítas, que também tomaram a si as tarefas militares. Como tal sucesso só pode ser explicado pela bondade e vontade de Deus, Venegas-Burriel lança a pergunta: quantos mais sucessos não adviriam para a Igreja Católica com a incorporação de novas populações, além do grau 40 de latitude, nos anos seguintes?

Mesmo que fosse apenas para manter as fronteiras atuais, o controle sobre os portos da Califórnia é estratégico para o comércio dos espanhóis com as ilhas Filipinas. Por falta de escala, prossegue ele, inúmeros espanhóis pereceram "nesta larguíssima travessia mesmo em tempos de profunda paz". Há sido também bastante comum o apresamento de galeões por corsários ou piratas inimigos, que se abrigaram na Califórnia ${ }^{29}$.

Acrescente-se a esses motivos antigos — que vêm ocorrendo desde séculos anteriores - os motivos modernos, recentes: os avanços russo e inglês em direção à costa noroeste da América ${ }^{30}$. Os russos não só têm estendido seu vastíssimo império em terras asiáticas, como começam a movimentar-se em direção às partes mais setentrionais do Mar do Sul, civilizando e construindo colônias em outros países, tendo já desembarcado na América. Por que não conquistariam a Califórnia se essa fosse abandonada pelos espanhóis? "Quem hoje reconhece costas e terras, amanhã poderá erigir colônias e estabelecimentos" ${ }^{\prime 31}$. Se um dia os ingleses acharem tal passagem, o que os impediria de, a partir dela, declararem-se donos das províncias do Novo México e Moqui, dos rios Gila e Colorado, e mesmo da parte setentrional da mesma Califórnia, que são as fronteiras de nossas missões e fortes ao norte da América? 'Os papéis públicos nos têm anunciado que os ingleses tencionam atravessar desde a Índia Oriental o Mar do Sul, e formar plantações e estabelecimentos nas costas da América ${ }^{32}$. É sempre importante se ter em mente, adverte-nos, que várias colônias que no presente pertencem aos ingleses, pertenceram aos espanhóis no passado. Daí Venegas-Burriel enfatizar que “(...) em todos os tempos, mas mais ainda no presente, tem sido e é importantíssima a religião ao Estado, a conquista da miserável Califórnia, em detrimento de outras terras mais felizes da América" ${ }^{33}$.

O medo que os espanhóis têm de serem invadidos, mesmo em suas partes mais distantes, é muitíssimo bem fundamentado, alerta Venegas-Burriel. O temor de que os ingleses se estabelecessem nas partes mais remotas de suas co- 
lônias, conectando essas partes com suas demais possessões, por exemplo, parece ao jesuíta "uma coisa bem provável". Mas ele próprio não considera a invasão inglesa um perigo iminente. O que ele pretende demonstrar é que a decisão ainda está nas mãos dos espanhóis. Isto demonstra que Venegas-Burriel parecia conhecer bem sua audiência, particularmente os receios da Coroa em relação às suas possessões ultramarinas que rodeavam a corte dos Bourbons. De fato, em um contexto no qual a Espanha perdia controle sobre suas colônias no Oriente e ao sul do continente americano, não parecia muito promissora a perspectiva de convencer Felipe V, da dinastia dos Bourbons, sobre o estabelecimento de novos portos e consolidação dos antigos na Califórnia. O argumento de Venegas-Burriel é no sentido de garantir a consolidação do império espanhol em região reconhecidamente problemática, afinando-se com a política de expansão territorial, agora em direção ao norte, garantindo não apenas a continuidade do comércio com as Filipinas como construindo um obstáculo para impedir o avanço de potências rivais, européias ou asiáticas.

A defesa de Clavijero sobre a importância estratégica da ocupação da Califórnia pela Coroa espanhola é semelhante à de Venegas, ainda que os dois jesuítas difiram no entusiasmo pela Califórnia e por seus habitantes. Ambos estão empenhados em evitar que outros povos aí se estabeleçam, pela utilidade dos portos californianos para o comércio com as Filipinas, enfim, visando à permanência da Califórnia como parte do império espanhol ${ }^{34}$. Para tal, tanto Clavijero quanto Venegas tentam provar a importância estratégica da Califórnia para a Coroa espanhola. Clavijero inclusive enfatiza, em seu relato histórico, como tal fato veio sendo reconhecido gradualmente pelos próprios representantes reais. Sem deixar de enaltecer a ação missionária jesuítica, ambos mencionam, às vezes com detalhes, as dificuldades enfrentadas pelos missionários em função das rebeliões indígenas. Se isso sugere uma abordagem crítica do empreendimento jesuíta, induz o leitor a valorizar ainda mais o empreendimento e seus objetivos altruístas. Ao aumentar a força e resistência do inimigo, era inevitável que crescesse também o mérito da vitória do trabalho dos jesuítas convertendo e civilizando os índios.

Clavijero vincula a história das missões jesuíticas na Califórnia à política real em relação à região, realçando as novas ordens do rei católico em favor dos jesuítas na região, as perigosas viagens feitas por missionários inacianos pelo rio Colorado, as pretensões extravagantes e as desordens dos pericúes. Detém-se também no elogio de alguns homens beneméritos da Califórnia, bem como na fundação e supressão de missões, concluindo com um balanço da situação do cristianismo na região por volta de 1767, do sistema de governo das missões e da expulsão dos jesuítas. Segundo Clavijero, a resposta real à Audiência do México autorizando a permissão aos padres Salvatierra e Kino para converter os índios da Califórnia só veio quando pôde certificar-se 
de que "nada pediam do erário real". Permitiu-lhes também o rei que, "às suas próprias expensas, pudessem levar soldados para a sua segurança, nomear o capitão e governador para administração da justiça e licenciar qualquer oficial ou soldado sempre que julgarem necessário"35. Admira-se mesmo com o fato de, entre tantos contratempos e perigos, os missionários jesuítas não terem se dividido. A perda de algumas missões por parte dos jesuítas deveu-se ao excessivo número de colonos que chegava em uma região onde os víveres não eram suficientes e à falta de apoio e proteção por parte do governo. Isso tudo de acordo com o relato do pe. Salvatierra, e nas repetidas cartas escritas ao vice-rei da Nova Espanha expondo o estado da colônia, os grandes gastos e a impossibilidade de pagar aos soldados com lismonas cada vez mais escassas e tardias. Implorava, por fim, a proteção do rei ${ }^{36}$.

Mesmo com o crescente afastamento dos jesuítas de suas missões, em 1735 o pe. Guillen escreveu ao arcebispo vice-rei sobre o lamentável estado do cristianismo na Califórnia. Vendo que não surtiu qualquer efeito, resolveu escrever diretamente ao rei. Seguiu-se à sua a carta do pe. Bravo alertando sobre o estado de miséria em que se encontravam as missões, que era em grande parte responsável pelas recentes rebeliões. Embora bem mais satisfatórios que os do pe. Guillen, os mantimentos enviados da Espanha estiveram muito aquém das necessidades, mas ainda assim conseguiu-se restabelecer certa ordem nas províncias setentrionais com a ajuda dos neófitos. E nelas foi enorme, segundo Clavijero, o clamor pelo retorno dos jesuítas:

Entraram em Loreto em uma procissão muito numerosa e bem ordenada, levando nos ombros todas as cruzes das missões; pediram com lágrimas que não os abandonassem à perdição os missionários que os haviam batizado e educado na vida cristã; protestaram que queriam viver e morrer na religião de Jesus Cristo que haviam abraçado; disseram que não era justo que todos sofressem a pena merecida por uns poucos descontentes, os quais estavam prontos a entregar ao capitão governador para que fossem castigados ${ }^{37}$.

Em suma, a vinculação entre o espiritual e o temporal fica evidenciada nos projetos jesuíticos visando a dar continuidade às missões e ao império espanhol na Califórnia. Informa-nos Clavijero que, durante a "Guerra da Califórnia", o rei, movido pelas representações dos jesuítas, ordenou que se estabelecesse, na parte austral da Califórnia, o projetado presídio para a segurança das missões. A condição, contudo, era que o capitão e os soldados não deveriam estar subordinados nem aos missionários nem ao capitão de Loreto, mas diretamente ao vice-rei. Tal atitude expressa o centralismo orientador das Reformas Bourbônicas. Mas o capitão nomeado, dom Esteván Rodriguez Lorenzo, "acostumado a respeitar Salvatierra, Ugarte e Píccolo, deferia com 
mais freqüência os ditames dos missionários do que queriam os inimigos dos jesuítas". De forma que a independência que se quis instaurar entre o temporal e o espiritual não durou mais que um ano e meio, devido às desordens que ocasionou. $\mathrm{O}$ vice-rei se viu forçado, então, a retornar às antigas disposições, que proibiam que se alterasse a forma de governo estabelecida na Califórnia pelo pe. Salvatierra. Do que conclui Clavijero: "Essa revogação de suas próprias ordens por um vice-rei que não era a favor dos jesuítas, basta para justificar o sistema de governo estabelecido pelo pe. Salvatierra na Califórnia”38.

Clavijero finaliza o livro lamentando ser esse o estado dos povos e dos jesuítas na Califórnia quando veio a ordem de expulsão em 25 de junho de 1767. Pois, quando os missionários se afastaram das missões, foram nelas mantidos os soldados para manter a ordem e impedir a deserção dos neófitos, enquanto chegavam os padres franciscanos. Sobre a chegada e estadia dos franciscanos nas missões fundadas pelos jesuítas, os documentos aos quais ele teve acesso foram cartas do México escritas naquele período, que atestam que os novos missionários viram com seus próprios olhos que a Califórnia não era como esperavam. Muitos deles abandonaram as missões e a península e voltaram a seus conventos, publicando por todas as partes que aquele país era inabitável e que os jesuítas "deviam agradecer muito ao rei por ter-lhes libertado daquela grande miséria" ${ }^{39}$. Depois da desistência dos franciscanos foram enviados à península da Califórnia religiosos dominicanos, sobre cuja obra Clavijero declara não dispor de informações. Deseja, contudo, que se empenhem eficazmente em "conservar a fé de Jesus Cristo entre os californianos e propagá-la entre os muitíssimos povos do Norte, afim de que todos conheçam, adorem e amem o seu Criador" ${ }^{40}$.

\section{CONCLUSÃo}

Embora ambos estejam envolvidos na causa de opor-se à campanha antijesuítica então em curso na Europa, e principalmente nos países ibéricos, a relação afetiva de Clavijero e Venegas-Burriel com a Califórnia é diferente. Venegas-Burriel preocupa-se com a manutenção da política imperial de proteção das missões jesuíticas na Califórnia, e apresenta as incursões inglesa e russa no noroeste da América do Norte como eventos que poderiam pôr em risco um empreendimento tão custoso aos jesuítas, ainda que altamente benéfico à Coroa, que lucra com ele mais do investe. Não afirma que o clima da Califórnia seja perfeito, mas sem dúvida aposta na possibilidade de intensificação de seu povoamento - até por razões estratégicas - e de conversão de tribos indígenas até então arredias. Clavijero, talvez por estar escrevendo al- 
guns anos depois, parece-me menos preocupado com tais aspectos, e especialmente bem menos seguro quanto ao sucesso do empreendimento.

Nos dois livros é possível visualizar — através da história do empreendimento jesuítico na Califórnia —, uma parte da história da complicada relação entre a Cia. de Jesus e o Estado espanhol no século XVIII: de complementaridade até meados do século, e de disputa, mais explícita ou velada, a partir de 1750. Os dois autores enfatizam a especificidade do caso californiano no interior do Vice-Reino da Nova Espanha, onde a Coroa ainda necessitava dos jesuítas em um período no qual a presença dos mesmos era extremamente incômoda na Espanha ou em regiões da Nova Espanha. Escrevendo em um momento bastante delicado no que concerne às relações dos jesuítas com a Coroa espanhola, então implementando as reformas bourbônicas, claramente antijesuíticas, Venegas-Burriel pisa em ovos. Faz questão de deixar clara sua situação de servidor zeloso da Coroa, ao mesmo tempo que profundo admirador do papel missionário dos jesuítas no norte da Nova Espanha e em outras regiões da América. Enquanto os espanhóis confrontam-se com tortuosos questionamentos sobre as causas do "atraso da Espanha" — grande parte deles atribuindo-os aos jesuítas —, Venegas-Burriel oferece uma avaliação diferente, porque positiva. Considera estar a Espanha na mesma situação de outras nações européias, nem mais atrasada nem mais evoluída. Os espanhóis não estariam desinformados sobre a natureza das doenças políticas que gradualmente os consumiam, ou ignorantes dos remédios a serem ingeridos. $\mathrm{O}$ que eles queriam era o poder de aplicá-los. Venegas-Burriel considerava que a possibilidade de restaurar o vigor da Monarquia espanhola residia na reativação da circulação de bens (comércio) através de todas as partes do império.

Chama a atenção, portanto, a ênfase do autor na sua situação de servidor leal do rei da Espanha. E não fala apenas em seu nome, senão como representante das missões jesuíticas então em pleno desenvolvimento na Califórnia, mantendo e expandindo as possessões do império espanhol, e ao mesmo tempo protegendo o dito império das ameaças russa e inglesa. Seu apoio à expansão do império implica, porém, a sugestão de medidas econômicas, políticas e missionárias destoantes daquelas prognosticadas pelas reformas "iluministas" de Carlos III. O autor não explicita qualquer referência ao medo, então disseminado na corte espanhola, em relação ao estabelecimento de um império jesuíta na América. Mas parece estar respondendo de certa forma a ele ao centrar seu argumento na comunidade de interesses entre a Cia. de Jesus e o império espanhol. Dessa forma, Venegas-Burriel e outros jesuítas no noroeste da Nova Espanha, embora contrários à política da Coroa espanhola, fazem a defesa do império espanhol contra as disputas fronteiriças entre ingleses e russos que o ameaçam exatamente na região da Califórnia. O que parece diferente do que estava acontecendo no Paraguai no mes- 
mo período, onde a disputa fronteiriça entre Portugal e Espanha confronta jesuíta com jesuíta. Em tais circunstâncias, o ultramontanismo da Cia. de Jesus não pôde fazer concessões à política nacionalista e de afirmação da soberania nacional dos Bourbons, como foi possível na Califórnia, onde espreita o "inimigo externo" russo ou inglês.

Clavijero tem uma abordagem semelhante do problema, mas a forma como lida com ele demonstra uma superioridade historiográfica significativa em relação a Venegas. Sua preocupação metodológica - especialmente no que se refere ao trato com as fontes — possibilita-nos melhor visualizar, em seus escritos, a conexão entre as mudanças na política imperial em relação ao Novo Mundo em geral e aos jesuítas em particular, com um relato da situação do ponto de vista de um jesuíta, mesmo não tendo ele sido um missionário na Califórnia. O importante é que, baseando-se em relatos de seus colegas — inclusive Venegas - de alguns viajantes e em cédulas reais expedidas entre 1730 e 1767, consegue oferecer ao leitor uma noção de conjunto não facilmente identificável nas notícias sobre a Califórnia até então publicadas, inclusive a de Venegas. Clavijero tem a seu favor o tempo, que lhe possibilita ver com mais clareza, mas principalmente a estruturação e organização das idéias, nas quais se evidencia um pertencimento muito mais evidente de Clavijero ao iluminismo, ainda que combinando ecleticamente o teológico (espiritual) com o temporal. Isso estava também presente em Venegas e em outros jesuítas setecentistas, mas não com a clareza e metodologia com que aparece em Clavijero.

\section{NOTAS}

'Este trabalho foi apresentado nas IX Jornadas sobre missões jesuíticas na PUC-SP, em outubro de 2002, como parte dos resultados da pesquisa de pós-doutorado na Latin American Center, da University of Maryland-College Park, USA, para a qual contei com uma generosa bolsa da Capes.

${ }^{2}$ CHEVALIER, François. “The formation of the Jesuit Wealth”. In MÖRNER, Magnus (ed.). The Expulsion of the Jesuits from Latin America, New York: Alfred A Knopf, 1965, pp. 94103. Ver também CHEVALIER, François. Land and Society in Colonial Mexico, Berkeley/Los Angeles: California University Press, 1963.

${ }^{3}$ CHEVALIER, F. Op. cit., p. 98.

${ }^{4}$ CLAVIJERO, Francisco Javier. História Antigua de México.(1780) Primeira edição del original escrito en castellano por el autor, 4 tomos, México, Editorial Porrua, S.A., 1945, p.2.

${ }^{5}$ Idem, p. IX. 
${ }^{6}$ Não especifica quais sejam, mas o mais provável é que esteja se referindo aos padres Kino e Salvatierra.

${ }^{7}$ CLAVIJERO, F.J. Op. cit., p.58.

${ }^{8} \mathrm{PAZ}$, Otávio. Sor Juana Inés de la Cruz. As armadilhas da fé. São Paulo: Cia das Letras, 2000.

${ }^{9}$ Ver introdução à primeira edição inglesa de VENEGAS, Miguel. A Natural and Civil History of California. London: J. Rivington and J. Flecher, 1759, cujo tradutor e provável autor do prólogo permanece anônimo.

${ }^{10}$ Dentre eles merece destaque o pe. jesuíta Peter Masten Dunne. "Lower California an Island”. In Mid-América. An Historical Quaterly, vol.XXV (New Series, vol.XXIV), 1953, pp.37-66.

${ }^{11} \mathrm{O}$ título do manuscrito original é Empresas Apostolicas de los PP. Missioneros de la Companhia de Jesus de la Provincia de Nueva España Obradas en la Conquista de California, debidas e Consegradas al Patrocínio de Maria Sanctissima, Conquistadora de Nuevas Gentes de su Sagrada Imagen de Loreto. Historiadas por al Padre Miguel Venegas en la Misma Compañia de Jesus. Devo tais informações ao interessantíssimo artigo escrito pelo jesuíta Peter Masten Dunne, que nos mostra, no decorrer da obra de Venegas-Burriel, uma expressiva resistência às recentes e às então não tão recentes descobertas sobre a Califórnia feitas por seus próprios colegas jesuítas. No manuscrito original de 1739 Venegas havia dedicado dois capítulos (X e XI do livro VIII) para refutar idéias dos exploradores jesuítas Kino e Ugarte. DUNNE, P.M. Op.cit., p.52.

${ }^{12}$ DUNNE, Peter Masten. Op. cit.

${ }^{13}$ As adições e correções feitas à sua obra são devidas mais ao afã dos jesuítas do século XVIII escreverem uma história científica do que a deficiências de seu trabalho. O’NEIL, Charles E. \& DOMINGUEZ, Joaquim Maria. Diccionario histórico de la Compañia de Jesus. Bibliográfico Temático, vol. IV.

${ }^{14}$ Os relatos de Vizcaino estão incluídos na Monarquia Indiana, de Juan de Torquemada. Também Venegas reproduz a Relación de el viaje del Capitan Vizcaino em sua Notícia de la California y de su conquista temporal y espiritual hasta el tiempo presente no Apêndice II, parte IV.

${ }^{15}$ VENEGAS, M. Op. cit., p.27.

${ }^{16}$ Os principais estudos a que se refere são: a) o do jesuíta Juan Bautista Duhalde, que fêz uma viagem, por ordem do czar da Rússia Pedro, o Grande, para averiguar a comunicação entre Ásia e América. Descripción Geográphica, Histórica, Chronológica, Politica y Physica del Império de la China y de la Tartaria Chinesa. Paris, 1735; b) Dom Jorge Juan e dom Antonio Ulloa, etc. Viaje a la America Meridional, hecho de orden de su Magestad para medir alguns grados de Meridiano Terrestre, y venir com ellos en conocimiento de la verdadera figura, y magnitud de la Tierra, con otras observaciones astronómicas y Phisicas. Madrid, 1748, 
$2^{\mathrm{a}}$ parte, livro 3, cap.7; c) Padre Kino: um mapa intitulado Paso por Tierra a la California, y sus confinantes: Nuevos Naciones, y Nuevas missiones de la Compañia de Jesus en la America Setentrional, descobierto, añadido y demarcado por el pe. Francisco Kino desde el ano 1692 hasta el de 1701; d) Dom Joseph Antonio de Villa-Señor y Sánchez. Teatro Americano. Descripción general de los Reinos y Províncias de la Nueva España, e sus Jurisdiciones. Mexico, 1746 y 1748, livro 6, cap.39. Venegas-Burriel aponta as concordâncias e discordâncias desses estudos com vários outros de viajantes britânicos e espanhóis.

${ }^{17}$ VENEGAS, M. Op. cit., vol. I, p.43.

${ }^{18}$ Foi nessas paragens que os pobres californianos estabeleceram as suas rancherías e os missionários as cabeceras de suas missões e dos Pueblos de Visita de cada uma. Cabeceras é o nome que se dá à população principal, na qual normalmente reside o missionário, que tem a seu cargo regularmente várias reduções ou pueblos pequenos, os quais visita e assiste.

${ }^{19}$ VENEGAS, M. Op. cit., vol.I, p.45. Como na península só existem dois rios - o dos Coras e o Rio Melegé - , as demais missões localizavam-se próximas a riachos cujas águas não desembocavam no mar, exceto em tempos de chuvas abundantes. As relaciones às quais o autor tem acesso não fazem, contudo, descrições detalhadas de tais rios e seus arredores, incluindo populações, portos, etc.

${ }^{20}$ VENEGAS, M. Op. cit., vol. I, pp.87-101.

${ }^{21}$ Esta cédula de Fernando V, com modificações, pode ser encontrada em Venegas-Burriel, II, p.501.

${ }^{22}$ CLAVIJERO, F. J. História de la Antigua o Baja California. México: Imprensa del Museo Nacional de Arqueologia, História y Etnografia, 1933, p. IX. A História da Califórnia foi escrita em italiano e traduzida pelo presbítero don Nicolas Garcia de San Vicente em 1862.

${ }^{23}$ VENEGAS, Miguel de. A Natural and Civil History of California. Posteriormente o pe. Jacobo Begert, jesuíta italiano que foi missionário na Califórnia por 17 anos, compôs em sua pátria, mas em língua alemã, uma nova história da Califórnia publicada em Munique em 1772. Embora tenha tido ali grande aceitação, Clavijero lamenta não poder tido acesso a ela.

${ }^{24}$ VENEGAS-BURRIEL, M. vol. 3, p. 12.

${ }^{25}$ Idem, pp.12-13.

${ }^{26} \mathrm{~A}$ relação entre expansão territorial e manutenção de uma ordem social político-econômica relativamente imutável tem sido uma característica dos países ibéricos desde a Idade Média, ainda presente nas tentativas portuguesa e espanhola de modernizar-se e, ao mesmo tempo, manter suas possessões americanas na segunda metade do século XVIII. Para uma visão mais ampla do "territorialismo ibérico", ver BARVOZA FILHO, Rubem. Tradição e Artifício. Iberismo e barroco na formação americana. Rio de Janeiro: IUPERJ; Belo Horizonte: Ed. UFMG, 2000.

${ }^{27}$ VENEGAS-BURRIEL, M. vol.3, pp.13-14. 
Beatriz Helena Domingues

${ }^{28}$ Idem, p. 15.

${ }^{29}$ Idem, p. 16.

${ }^{30}$ Idem, pp.16-17.

${ }^{31}$ Idem, p.17.

${ }^{32}$ Idem, p. 17.

${ }^{33}$ Idem, p.18.

${ }^{34} \mathrm{O}$ relato histórico de Clavijero sobre as tentativas patrocinadas pela Coroa espanhola para conquistar a Califórnia, se parece bem mais com as descrições dos séculos XIX e XX do que com o de Venegas, por exemplo.

${ }^{35}$ CLAVIJERO, F.J. Op. cit., p.84. Vide reprodução do documento real na nota 7, p.132.

${ }^{36}$ Idem, pp. 95-97.

${ }^{37}$ Idem, p. 187.

${ }^{38}$ Idem, p. 192.

${ }^{39}$ Idem, pp. 248-9.

${ }^{40} I d e m$, p. 249. Durante os setenta anos em que estiveram na Califórnia, os jesuítas fundaram 18 missões, mas quatro delas foram suprimidas. Em 1768 eram 14, quatro entre os 280 guaiacuras e nove entre os cochimés (pp. 236-238). Clavijero faz uma detalhada descrição das missões descrevendo sua arquitetura, funcionamento, educação, etc. (pp.239-241).

Artigo recebido em 11/2002. Aprovado em 4/2003.

Revista Brasileira de História, vol. 23, $\mathrm{n}^{\circ} 45$ 